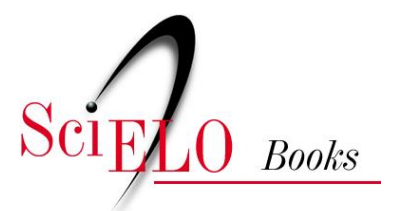

\title{
Capitanias hereditárias
}

\author{
Capistrano de Abreu
}

ABREU, C. Capitanias hereditárias. In: Capítulos da história colonial [online]. Rio de Janeiro: Centro Edelstein de Pesquisa Social, 2009. pp. 32-39. ISBN: 978-85-7982-071-7.

https://doi.org/10.7476/9788579820717.0005.

\section{() pobuntiv}

This work is free of known copyright restrictions. http://creativecommons.org/publicdomain/mark/1.0/

Este trabalho está livre de restrições de direito de autor e/ou de direitos conexos conhecidas.

http://creativecommons.org/publicdomain/mark/1.0/

Esta obra está libre de restricciones conocidas de derechos autorales. http://creativecommons.org/publicdomain/mark/1.0/ 


\section{CAPITANIAS HEREDITÁRIAS}

A tomadia de La Pèlerine, a feitoria francesa fundada em Pernambuco, notícias de preparativos para fundarem-se outras, espancaram finalmente a inércia real. Escrevendo a Martim Afonso de Sousa a 1528 de setembro de 1532, anuncia-lhe el-rei a resolução de demarcar a costa, de Pernambuco ao rio da Prata, e doá-la em capitanias de cinquenta léguas: a de Martim teria cem; seu irmão Pero Lopes seria um dos donatários.

A chegada do jovem guerreiro vitorioso em Pernambuco mostrou mais uma vez a iminência do perigo. Talvez a isto se devam certas medidas desde logo tomadas ou pelo menos discutidas: liberdade ampla de emigrar para o Brasil, preparo de uma armada de três caravelas, cada uma com dez a doze condenados à morte, "per farli desmontar in terra, azió habiano a domestigar quel paese, rispetto per non metter boni homini dabene a pericolo", assegurava, a 16 de julho de 1533, o veneziano Pietro Caroldo, a quem devemos esta notícia. Tal armada veio efetivamente?

Sua vinda explicaria uma porção de pontos obscuros. Os documentos mais antigos da doação das capitanias datam de 1534. A demora entre o projeto e a execução pode explicar-se pela vontade régia de esperar a volta de Martim Afonso, ou pela dificuldade de redigir as complicadas cartas de doações e os forais que as acompanham ou, finalmente, pela falta de pretendentes à posse de terras incultas, impróprias para o comércio desde o começo. Admira, até, como houve doze homens capazes de empresa tão aleatória. A nenhum dos membros da alta fidalguia tentou a perspectiva de semear povos.

Os donatários sairam em geral da pequena nobreza, dentre pessoas práticas da Índia, afeitas ao viver largo da conquista, porventura coactas na malhas acochadas da pragmática metropolitana. Muitos nunca vieram ao Brasil, ou desanimaram com o primeiro revés. el-rei cedeu às pessoas a quem doou capitanias alguns dos direitos reais, levado pelo desejo de dar vigor ao regime agora organizado; muitas concessões fez também como administrador e grão-mestre da Ordem de Cristo.

Em tudo agiu, considerando quanto serviço de Deus e meu e proveito dos meus reinos e senhorios, e dos naturais e súditos deles é ser a minha terra e costa do Brasil mais povoada do que até agora foi, assim para se nela haver de celebrar o culto e ofícios divinos, e se exaltar a nossa santa fé católica, com trazer e provocar a ela os naturais da dita terra infiéis e idólatras, como por o muito proveito que se seguirá a meus reinos e senhorios, e aos naturais e súditos deles de se a dita terra povoar e aproveitar.

Os donatários seriam de juro e herdade senhores de suas terras; teriam jurisdição civil e criminal, com alçada até cem mil réis na primeira, com alçada no crime até morte natural para escravos, índios, peões e homens livres, para pessoas de mor qualidade até dez anos de degredo ou cem cruzados de pena; na heresia (se o herege fosse entregue pelo eclesiástico), traição, sodomia, a alçada iria até morte natural, qualquer que fosse a qualidade do réu, dando-se apelação ou agravo somente se a pena não fosse capital.

Os donatários poderiam fundar vilas, com termo, jurisdição, insígnias, ao longo das costas e rios navegáveis; seriam senhores das ilhas adjacentes até distância de dez léguas da costa; os ouvidores, os tabeliães do público e judicial seriam nomeados pelos respectivos donatários, que poderiam livremente dar terras de sesmarias, exceto à própria mulher ou ao filho herdeiro.

Para os donatários poderem sustentar seu estado e a lei de nobreza, eram-lhe concedidas dez léguas de terra ao longo da costa, de um a outro extremo da capitania, livres e isentas de qualquer direito ou tributo exceto o dízimo, distribuídas em quatro ou cinco lotes, de modo a intercalar-se entre um e outro pelo menos a distância de duas léguas; a redízima (1/10 da dízima) das rendas pertencentes à coroa e ao mestrado; a vintena do paubrasil (declarado monopólio real, como as especiarias), depois de forro de todas as despesas; a dízima do quinto pago à coroa por qualquer sorte de pedraria, pérolas, aljôfares, ouro, prata, coral, cobre, estanho, chumbo ou outra qualquer espécie de metal; todas as moendas dágua, marinhas de sal e quaisquer outros engenhos de qualquer qualidade, que na capitania e governança se viessem a fazer; as pensões pagas pelos tabeliães; o preço das passagens dos barcos nos rios que os pedissem; certo número de escravos, que poderiam ser vendidos no reino, livres de todos os direitos; a redízima dos direitos pagos pelos gêneros exportados, etc. 
Os forais asseguravam aos solarengos: sesmarias com a imposição única do dízimo pago ao mestrado de Cristo; permissão de explorar as minas, salvo o quinto real; aproveitamento do pau-brasil dentro do próprio país; liberdade de exportação para o reino, exceto de escravos, limitados a número certo, e certas drogas defesas (pau-brasil, especiarias, etc.); direitos diferenciais que os protegeriam da concorrência estrangeira; entrada livre de mantimentos, armas, artilharia, pólvora, salitre, enxofre, chumbo e quaisquer cousas de munições de guerra; liberdade de comunicação entre umas e outras capitanias do Brasil.

Representantes do poder real só havia feitores, almoxarifes e escrivães, incumbidos de arrecadar as rendas da coroa. Para várias capitanias existem nomeações de um vigário e vários capelães: sempre elrei ao lado do grão-mestre de Cristo.

Nas terras dos donatários não poderiam entrar em tempo algum corregedor, alçada ou outras algumas justiças reais para exercer jurisdição, nem haveria direitos de siza, nem imposições, nem saboarias, nem imposto de sal.

Em suma, convicto da necessidade desta organização feudal, d. João III tratou menos de acautelar sua própria autoridade que de armar os donatários com poderes bastantes para arrostarem usurpações possíveis dos solarengos vindouros, análogas às ocorridas na história portuguesa da média idade. Ao ouvidor da capitania, com ação nova a dez léguas de sua assistência e agravo e apelação em toda ela, caberia o mesmo papel histórico dos juízes de fora no além-mar.

Para evitar lutas como as que grassaram entre a coroa ainda enfraquecida e os vassalos prepotentes, proibiu-se de modo absoluto "partir [a capitania e governança], nem escaimbar, espedaçar, nem em outro modo alhear, nem em casamento a filho ou filha, nem a outra pessoa dar, nem para tirar pai ou filho ou outra alguma pessoa de cativo, nem por outra cousa ainda que seja mais piadosa porque minha tenção e vontade é que a dita capitania e governança e cousas ao dito capitão e governador nesta doação dadas hão de ser sempre juntas e se não partam nem alienem em tempo algum". As dez ou mais léguas de terras dadas aos donatários, espaçadas entre si e alienáveis em fatiotas, corresponderiam aos reguengos lusitanos.
As capitanias foram doze, embora divididas em maior número de lotes. Começavam todas à beira-mar, e prosseguiram com a mesma largura inicial para o ocidente, até a linha divisória das possessões portuguesas e espanholas acordada em Tordesilhas, linha não demarcada então, nem demarcável com os conhecimentos do tempo. Tàcitamente fixou-se o limite na costa de Santa Catarina ao Sul, e na costa do Maranhão ao Norte. A testada litorânea agora dividida estendia-se assim por 735 léguas.

No plano primitivo a demarcação devia ir de Pernambuco ao rio da Prata, meta de que afinal ficou cerca de 12 graus afastada; nele não entrava a costa de Este-Oeste que, entretanto, foi demarcada. Para a última decisão é possível afluíssem as notícias de Diogo Leite, incumbido de explorar aquela zona. Só por considerações internacionais se poderia explicar a fixação tácita dos limites do Brasil em $28^{\circ} 1 / 3$. O rio da Prata fora descoberta portuguesa; mas os espanhóis já aí tinham estado bastante tempo, derramado sangue e arriscado empresas: a eles competia por todos os direitos, a começar pelo tratado de Tordesilhas.

A divisão das donatárias ainda não foi descrita tão concisa e geográficamente como nos seguintes termos de D’Avezac, o único que conseguiu dar certa forma a esta matéria essencialmente refratária: o limite extremo da mais meridional destas capitanias, concedida a Pero Lopes de Sousa, é determinado nas próprias cartas de doação por uma latitude expressa de $28^{\circ}$ 1/3; confrontava, um pouco ao Norte de Paranaguá, com a de S. Vicente, reservada a Martim Afonso de Sousa, e que se estendia do lado oposto até Macaé, ao Norte de Cabo Frio, desenvolvendo assim mais de cem léguas de costa, mas em duas partes que encravavam, desde São Vicente até a embocadura do Juquiriquerê, a de Santo Amaro, de dez léguas, adjudicada a Pero Lopes, o irmão de Martim Afonso.

Ao Norte dos domínios deste estava a capitania de S. Tomé, cujas trinta léguas iam expirar junto de Itapemirim; era o lote de Pero de Góis, irmão do célebre historiador Damião de Góis. Em seguida vinha a capitania do Espírito Santo, outorgada a Vasco Fernandes Coutinho, cujo linde ulterior era marcado pelo Mucuri, que a separava da capitania de Porto Seguro, atribuída a Pero do Campo Tourinho; esta prosseguia pelo espaço de cinquenta léguas até a dos Ilhéus, obtida por Jorge de Figueiredo Correia, igualmente de cinquenta léguas, cujo termo chegava rente à Bahia. 
A capitania da Bahia, doada a Francisco Pereira Coutinho, se estendia até o grande rio de S. Francisco; além estava a de Pernambuco, adjudicada a Duarte Coelho, e que contava sessenta léguas até o rio Iguaraçu, junto ao qual Pero Lopes possuía terceiro lote de trinta léguas, formando sua capitania de Itamaracá até a baía da Traição. Neste lugar começava, para se estender sobre um litoral de cem léguas até angra dos Negros, a capitania do Rio Grande, dada em comum ao grande historiador João de Barros e a seu associado Aires da Cunha; da angra dos Negros ao rio da Cruz quarenta léguas de costas constituíam o lote concedido a Antônio Cardoso de Barros: o rio da Cruz ao cabo de Todos-os-Santos, vizinho do Maranhão, eram adjucadas setenta e cinco léguas ao vedor da fazenda Fernano Alvares de Andrade: e além vinha enfim a capitania do Maranhão, formando segundo lote para a associação de João de Barros e Aires da Cunha, com cinquenta léguas de extensão sobre o litoral, até a abra de Diogo Leite, isto é, até cerca da embocadura do Turiaçu.

Das setecentas e trinta e cinco léguas de litoral demarcado para as capitanias podemos desde já apartar as duzentas e sessenta e cinco doadas a João de Barros, Fernando Álvares, Aires da Cunhas e Antônio Cardoso de Barros. Os esforços para ocupá-las mangraram; o povoamento fez-se mais tarde, com gente nascida ou estabelecidas em outros pontos do Brasil: representam uma formação secundária na história pátria. Convém também apartar as duzentas e trinta e cinco léguas demarcadas entre o extremo da capitania dos Ilhéus na baía de Todos-os-Santos e o rio Curupacé, e mais quarenta léguas de Cananeia para a terra de Sant'Ana. Aqui houve logo tentativas de povoamento: ainda hoje existem vilas fundadas na quarta década do século XVI; mas os colonos tiveram pela frente a mata virgem, os rios encachoeirados, as serranias ínvias, não souberam vencê-los e só impulsionaram a história do Brasil quando os venceram. A primeira vitória decisiva foi ganha no rio de Janeiro, já no século XVIII, com o auxílio dos paulistas; desde então o Rio figura como fator cada vez mais importante. Outros pontos, como Vitória, Porto Seguro, Ilhéus, esperaram ou estão esperando as vias férreas.

Restam as cento e quarenta léguas estendidas da baía da Traição à de Todos-os-Santos, as cinquenta e cinco léguas inseridas entre o Curupacé e Cananeia, em outros termos: a capitania de Duarte Coelho, parte da de Martim Afonso de Sousa, os troços da capitania da Bahia depois da morte do primitivo donatário.
A história do Brasil no século XVI elaborou-se em trechos exíguos de Itamaracá, Pernambuco, Bahia, Santo Amaro e S. Vicente, situados nestas cento e noventa e cinco léguas de litoral.

Martim Afonso conservara-se na vila de S. Vicente à espera da gente mandada às minas que, segundo a tradição, trucidaram os Carijós do Iguaçu, quando tornava da sua arriscada expedição. Uma carta régia trazida por João de Sousa informou-o dos novos planos de colonizar, deixando-lhe ao arbítrio permanecer ou tornar para o Reino. Em começo de 33 partiu para Portugal. Desde então seus feitos pertencerem a outras partes do mundo.

Em seu lugar ficou governando no civil, concedendo sesmarias, provendo ofícios, o padre Gonçalo Monteiro, também vigário. O governo das armas exerceram-no Pero de Góis e Rui Pinto. O primeiro quis expulsar do Iguape alguns espanhóis que ali se refugiaram, vindo do Paraguai. Surtiu-lhe mal o lance. Os espanhóis derrotaram a força, aprisionaram o comandante, invadiram e saquearam S. Vicente. Ou achasse meio de fugir, ou aos inimigos bastasse o escarmento, já estava no velho mundo em 1536, como se concluiu do foral de sua capitania datado de 26 de fevereiro.

Desde Bertioga até o Cabo Frio continuavam implacáveis os Tupinambás, combatendo e atacando por terra e por mar contra os Peró, e a favor dos Maïr. Num dos combates sucumbiu Rui Pinto. Cunhambebe, truculento maioral tamoio, guardava entre os outros troféus o hábito e a cruz de Cristo deste cavaleiro.

Aparece-nos entre os primeiros povoadores Brás Cubas, jovem criado de Martim Afonso, que aportou a S. Vicente em 1540, governou mais de uma vez a terra, guerreou contra os Tamoios, fortificou Bertioga, entrada preferida por estes inimigos, e fundou a vila de Santos, que possuía melhor porto e facilmente superou a primogênita de Martim Afonso. Mais tarde empenhou-se na cata de minas, e consta haver achado algum ouro.

À roda destas vilas fundaram engenhos, além dos portugueses, os flamengos Schetz ou Esquertes, como o pronunciava o povo, e os Dorias, genoveses. Diz-se até, porém não deve ser exato, que desta procedem as canas plantadas em outras capitanias. Tais engenhos, com as distâncias e a raridade de comunicações, deviam ter desenvolvimento medíocre. 
Da vila fundada em Piratininga conhecemos a mera existência ou pouco mais. A situação no descampado dificultava surpresas inimigas. O trânsito do Paraguai dava-lhe algum movimento. As cabanas de João Ramalho e dos mamalucos seus filhos e parentes, no outro lado da serra donde as águas já corriam para o Prata, apregoavam a vitória alcançada sobre a mata virgem do litoral, vitória obtida aqui mais cedo que em qualquer outra parte do Brasil, porque os colonos apenas continuaram a obra dos indígenas, já achando aberto por cima de Paranapiacaba e aproveitando a trilha dos Tupiniquins.

Na capitania de Pernambuco, depois de estabelecido Igaraçu, Duarte Coelho passou algumas léguas mais ao Sul, e assentou a capital de seus domínios em Olinda. O porto de somenos capacidade bastava às pequenas embarcações. A vizinhança dos Tabajaras (Tupiniquins) compensava as investidas constantes dos Petiguares (Tupinambás). A energia do donatário continha a turbulência dos colonos. Nas várzeas surgiam canaviais e engenhos; a lavoura de mantimentos aproveitou os altos: pau-brasil existia no litoral e no sertão; e estando esta capitania, de todas a mais oriental, a menor distância do Reino, aqui mais que alhures frequentavam os navios de além-mar, e prosperava o comércio. Os mares piscosos traziam a fartura, e alentavam a costeagem; caravelões espantavam os franceses, que desde então começaram a evitar aquelas paragens. O nome de Nova Lusitânia dado pelo donatário à sua colônia, se por um lado figura esperanças de futuro, simbolizava por outro o orgulho da própria obra. Nas armas concedidas por d. João III em 6 de junho de 1545 cinco castelos representavam os cinco centros de povoações criadas por Duarte Coelho. Infelizmente conhecemos só Igaraçu, Olinda e, quiçá, Paratibe.

Da capitania de Itamaracá foram recursos para a de Pernambuco, quando os Petiguares puseram cerco em Igaraçu e levaram-no aos últimos apuros. Mais tarde as relações estremeceram. Queixa-se Duarte Coelho de desrespeitos constantes à sua autoridade; de Itamaracá teve de retirar-se um capitão, por Duarte Coelho haver mandado dar-lhe uma cutilada: a pequena distância gerou dissensões. Contudo, os colonos de Pero Lopes tiveram a habilidade de conciliar os Tupinambás da serra, e como não avançaram pelo litoral para as terras do Paraíba, centro dos Petiguares amigos dos franceses, seu desenvolvimento correu pacífico e contínuo por algum tempo.
Largos recursos naturais facilitavam a obra de Francisco Pereira Coutinho: baía vasta como um mediterrâneo, esteiros numerosos franqueando entrada a cada passo, correntes numerosas para moverem engenhos, matas virgens ao lado de terrenos mal vestidos; onde o gado podia medrar à lei da natureza, situação vantajosa no centro das outras capitanias.

Faltava pau-brasil na vizinhança, mas o afastamento dos franceses, daí resultante, compensava bem a pobreza e, não instigados pelos franceses, os Tupinambás mostrariam disposições menos malévolas. Por que não foi avante, com tudo isso, Francisco Pereira Coutinho? Não soube dominar os elementos que importou, nem se impôs à indiada das adjacências. Tais apuros sofreu quem pereceria sem os socorros mandados dos Ilhéus.

Mais tarde recolheu-se a Porto Seguro, cansado e velho, pouco disposto a continuar; mas os ânimos serenaram na Bahia, e tornava esperançado, quando foi morto ao desembarcar. Nas lutas com os índios mandara matar um dos cabecilhas: prisioneiro agora, foi ritualmente sacrificado por um irmão do finado, de cinco anos, tão pequeno que foi preciso segurarem-lhe a massa do sacrifício, segundo tradição conservada num escrito jesuítico. 